\title{
KAJIAN ARKEPTIPAL DAN NILAI KEARIFAN LOKAL LEGENDA DI KOTA PURWOREJO SERTA RELEVANSINYA SEBAGAI BAHAN AJAR MATA KULIAH KAJIAN PROSA
}

\author{
Nurul Setyorini ${ }^{1} \&$ Suci Riskiana ${ }^{2}$ \\ Dosen PBSI FKIP Universitas Muhammadiyah Purworejo \\ Email: nurulsetyorini72@yahoo.com
}

\begin{abstract}
ABSTRAK
Penelitian ini bertujuan untuk mendeskripsikan: (1) kajian arkeptipal legenda di Purworejo; (2) nilai kearifan lokal legenda di Kota Purworejo, dan (3) relevansi kajian arkeptipal dan nilai kearifan lokal di Kota Purworejo sebagai bahan ajar dalam mata kuliah Kajian Prosa Fiksi. Metode penelitian yang digunakan dalam penelitian ini adalah deskriptif kualitatif. Penelitian ini dilakukakan di beberapa desa wilayah Kabupaten Purworejo yang memiliki cerita legenda. Objek kajian penelitian ini terdiri dari dua, yaitu objek formal dan objek material. Teknik pengumpulan data yang digunakan dalam penelitian ini adalah wawancara, sedangkan teknik analisis data yang peneliti gunakan adalah analisis isi. Selanjutnya, data disajikan melalui teknik informal. Hasil penelitian ini, pertama kajian arkeptipal, kajian arkeptipal dalam legenda di Purworejo membahas empat legenda saja, seperti legenda Dewi, Candi Ngasinan, Banyuurip, dan Brengkelan. Kajian tersebut terdapat tiga bahasan, yaitu tokoh arkeptipal, peristiwa arkeptipal, dan simbol arkeptipal. Tokoh arkeptipal dalam legenda rata-rata adalah seorang petualang yang menemukan hutan kemudian membabat alas menjadi desa. Tokoh tersebut menjadi nama desa tersebut. Peristiwa arkeptipal berkaitan dengan peristiwa babat alas dan peperangan. Simbol arkeptipal berupa bahasa, peninggalan, dan senjata. Kedua kerifan lokal, kearifan lokal yang ada dalam legenda berupa upacara adat, bahasa, dan mata pencaharian. Ketiga relevansi sebagai bahan ajar, penelitian ini relevan sebagai bahan ajar dalam mata kuliah pengkajian sastra baik materi psikologi sastra maupun antropologi sastra. Bahan ajar tersebut bisa berwujud contoh pengkajian maupun bahan pengkajian.
\end{abstract}

Kata kunci: Arketipal, Legenda, dan Bahan Ajar.

\begin{abstract}
This research aimed to describe: (1) archetypal review ofthe legends in Purworejo; (2) values of local wisdom of the legends in Purworejo, and (3) Relevance of archetypal review and values of local wisdom in Purworejo as aninstructional material of the course Fiction Prose Review. The research methods used were qualitative descriptive methods. This research was conducted in some villages in Purworejo Regency which had legends. The research objects consisted of two objects, namely formal object and material object. The data collection technique used was interview, whereas the data analysis technique used was content analysis. Then, the data were presented using informal technique. The results of this research, firstly, the archetypal review of the legends in Purworejo, which discussed only four legends, including the legends of Dewi, Candi Ngasinan (Ngasinan Temple), Banyuurip and Brengkelan. This review discussed three points, namely archetypal characters, archetypal events and archetypal symbols. The archetypal characters of the legends are on average adventurers who discovered forests and cleared the forests to be made villages. The name of the characters later were used as the names of the villages. The archetypal events were related to the events of clearing and battle. The archetypal symbols were in the forms
\end{abstract}


of language, heritage and weapons. Secondly, the local wisdom, which was in the forms of traditional ceremonies, language and livelihood. Thirdly, the relevance as aninstructional material, which discussed that this research is relevant to be used as aninstructional material in the course of literary review, either literary psychology or literary anthropology. The instructional material could be in the forms of review examples or review materials.

Key word: Archetypal, Legends, and Instructional material.

\section{PENDAHULUAN}

Sastra merupakan refleksi dari pengalaman hidup pengarangnya. Pengalaman hidup tersebut bisa berwujud pengalaman pengarang sendiri dan pengalaman orang lain yang telah melalui perenungan, penghayatan, dan penjiwaan sehingga menjadi nilai-nilai yang bermakna bagi kehidupan manusia. Sastra merupakan dunia imajinasi yang diciptakan oleh pengarang. Imajinasi tersebut berasal dari diri sendiri dan lingkungan sekitar pengarang, imajinasi yang diciptakan diri sendiri berhubungan dengan kondisi psikologis yang dialami oleh pengarang. Karya sastra merupakan sebuah karya yang mengedepankan aspek keinda-han di samping keefektifan penyampaian pesan (Setyorini, 2015:289). Oleh karena itu, sastra memiliki unsurunsur berupa pikiran, pengalaman, ide, perasaan, semangat, kepercayaan (keyakinan), ekspresi atau ungkapan, bentuk dan bahasa. Hal ini sejalan dengan itu, Wicaksono (dalam Setyorini, 2014:22), mengemukakan bahwa sastra merupakan seni kreatif yang objeknya adalah manusia dan kehidupan dengan menggunakan bahasa sebagai mediumnya.

Sebagaimana kita ketahui sastra tidak bisa dilepaskan dari kehidupan kita. Chamamah Soretno (Wiyatmi 2010:197), menjelaskan bahwa secara pragmatik peran karya sastra dalam masyarakat antara lain karena dapat menggerakan pembacanya agar bersikap dan berperilaku dan bertindak sebagaimana yang disarankan oleh teksnya. Kehadiran karya sastra diharapkan mampu menggerakkan masyarakat menjadi le- bih peka dan reponsif dalam menghadapi gejala yang berkembang dalam masyarakat. Semenjak kita masih balita, kita telah mengenal yang namanya sastra, yaitu berupa dongeng-dongeng yang diceritakan oleh orang tua ataupun kakak-kakak kita. Seiring berjalannya waktu sastra pun semakin kita kenal dan tidak hanya berupa dongeng, melainkan bentuk sastra lainnya seperti puisi, cerpen, novel ataupun film yang bisa digolongkan pada jenis karya sastra puisi, prosa, dan drama. Hal tersebut, sejalan dengan pendapat (Nurgiyantoro, 2010:10), karya sastra menurut ragamnya dibagi menjadi tiga, yaitu prosa, puisi, dan drama. Karya sastra jenis prosa biasanya diungkapkan melalui bentuk fiksi atau cerita rekaan. Menurut Waluyo (2011:1) prosa fiksi, yaitu jenis prosa yang dihasilkan dari proses imajinasi. Lebih lanjut, Dundes ([e], 1984:5), menyebutkan bahwa yang dimaksud dengan prosa naratif lisan di sini adalah prosa naratif yang digolongkan Bascom menjadi mitos (myth), legenda (legend), dan cerita rakyat (folktale).

Purworejo merupakan salah satu kota kecil di Provinsi Jawa Tengah, Indonesia yang memiliki banyak legenda. Menurut Bascom (dalam Dundes [ed], 1984:9), legenda adalah prosa naratif lisan yang kisahnya dianggap oleh masyarakat pemiliknya sebagai fakta yang benar-benar terjadi. Tokoh ceritanya adalah manusia (human), kisahnya terjadi pada masa lampau yang belum berapa lama (recent past), diyakini bersifat sekuler (secular) atau sakral (sacred). Legenda berkisah tentang migrasi 
penduduk, peperangan antar kelompok, pahlawan pada masa lalu, pergantian kekuasaan raja, dsb.

Berdasarkan pengamatan peneliti, cerita legenda yang ada di kota Purworejo tersebut masih banyak yang berwujud prosa naratif lisan. Sekalipun sudah ada beberapa yang sudah tertulis, seperti Serat Babad Banyuurip, Kisah Bedug Raksasa dan Masjid Agung Purworejo, dan diantaranya ditulis di beberapa blog internet. Selain itu, dari beberapa legenda tersebut belum banyak yang dijadikan bahan penelitian dengan pendekatan arkeptipal. Beberapa contoh legenda yang ada di kota ini, antara lain, legenda "Sumpah Banyu Mendiro", legenda asal usul desa Tursino Kutoardjo, riwayat desa Semawung Purworejo, asal usul nama Bruno Purworejo, asal usul Kaligesing, legenda Tundan Obor, asal usul desa Kalinongko, kisah Nyi Rawong, asal usul desa Lowano, dll.

\section{LANDASAN TEORETIS}

Cerita legenda yang banyak tersebar di Kota Purworejo, tetapi masih berwujud prosa naratif lisan membuat daya tarik bagi peneliti untuk menelitinya. Adapun pendekatan yang akan peneliti gunakan adalah kajian arkeptipal, sebab objek kajian ini menarik untuk diteliti berdasarkan perspektif antropologi. Menurut Sudjijono (2002:40), kajian dengan pendekatan arketipal juga dapat digunakan untuk menggali warisan klasik, nilai-nilai primordial yang khas, yang dijadikan rujukan dalam aktivitas kehidupan masyarakat tersebut. dari masa ke masa. Pemahaman dan apresiasi nilai-nilai kenusantaraan ini menjadi signifikan, terutama dalam menghadapi proses globalisasi wujud dan nilai kebudayaan bangsa adikuasa akhir-akhir ini.

Dalam kajian sastra lisan, pendekatan ini (di Indonesia) masih jarang digunakan. Hal tersebut, misalnya, tampak dalam hasil-hasil skripsi, disertasi, atau publikasi hasil penelitian yang pernah ada. Padahal, pendekatan ini memiliki kelebihan, di antaranya, mampu menjelaskan segi menarik objek kajian, karya seni, termasuk prosa naratif/sastra lisan yang kualitas estetiknya tidak terlalu tinggi, tetapi karya tersebut sangat populer di kalangan masyarakat pemiliknya (Griffith, 1982:78). Kepopuleran tersebut pantas dan patut dipertanyakan, dipahami, dan diungkapkan alasan dan sebab-musababnya dalam suatu kegiatan penelitian. Kajian dengan pendekatan arketipal juga dapat digunakan untuk menggali warisan klasik, nilai-nilai primordial yang khas, yang dijadikan rujukan dalam aktivitas kehidupan masyarakat tsb. dari masa ke masa. Pemahaman dan apresiasi nilai-nilai kenusantaraan ini menjadi signifikan, terutama dalam menghadapi proses globalisasi wujud dan nilai kebudayaan bangsa adikuasa akhir-akhir ini.

Legenda di kota Purworejo yang jumlahnya banyak sebenarnya merupakan bagian dari kerifan lokal. Hal tersebut dikarenakan legenda termasuk sastra lisan yang mencakup ekspresi kesusastraan. Ekspresi kesusastraan tersebut nampak karena dalam cerita legenda terdapat beberapa nilai dan warisan budaya. Kearifan lokal (local wisdom) dalam disiplin antropologi dikenal juga dengan istilah local genius. Local genius ini merupakan istilah yang mula pertama dikenalkan oleh Quaritch Wales. (Ayatrohaedi, 1986). Para antropolog membahas secara panjang lebar pengertian local genius ini. Antara lain Haryati Soebadio mengatakan bahwa local genius adalah juga cultural identity, identitas/kepribadian budaya bangsa yang menyebabkan bangsa tersebut mampu menyerap dan mengolah kebudayaan asing sesuai watak dan kemampuan sendiri (Ayatrohaedi, 1986:18-19). Sementara itu Moendardjito (dalam Ayatrohaedi, 1986:40-41) mengatakan bahwa 
unsur budaya daerah potensial sebagai local genius karena telah teruji kemampuanya untuk bertahan sampai sekarang.

Selanjutnya, menurut Moendardjito (Ayat, 1986:40-41) mengatakan bahwa unsur budaya daerah potensial sebagai local genius karena telah teruji kemampuannya untuk bertahan sampai sekarang. Ciri-cirinya adalah: (1) mampu bertahan terhadap budaya luar, (2) memiliki kemampuan mengakomodasi unsur-unsur budaya luar, (3) mempunyai kemampuan mengintegrasikan unsur budaya luar ke dalam budaya asli, (4) mempunyai kemampuan mengendalikan, dan (5) mampu memberi arah path perkembangan budaya.

Penelitian terkait kearifan lokal ini penting dan menarik untuk dikaji, karena hasil penelitian ini nanti dapat dimanfaatkan sebagai landasan dalam pengambilan berbagai kebijakan pembangunan bangsa di Indonesia, terutama di kota Purworejo. Selain itu, dengan adanya kajian legenda tentang kearifan lokal maka akan memperbanyak khasanah sastra utamanya prosa naratif lisan dari kota Purworejo.

Kajian Arketipal legenda di kota Purworejo merupakan salah satu materi dalam pembelajaran Kajian Prosa. Dengan demikian, maka kajian ini dapat dijadikan sebagai bahan ajar dalam mata kuliah kajian prosa. Bahan ajar merupakan segala bahan (baik informasi, alat, maupun teks) yang disusun secara sistematis, yang menampilkan sosok utuh dari kompetensi yang akan dikuasai peserta didik dan dalam proses pembelajaran dengan tujuan untuk perencanaan dan penelaahan implementasi pembelajaran (Prastowo, 2012:3). Pelaksanaan pembelajaran berpedoman pada kurikulum. Kurikulum merupakan acuan mengajar bagi guru yang mengandung tujuan yang harus dicapai siswa. Dalam mewujudkan pembelajaran diperlukan sumber-sumber belajar untuk menun- jang pelaksanaan kegiatan. Bahan ajar merupakan seperangkat materi yang disusun secara sistematis sehingga tercipta lingkungan atau suasana yang memungkinkan siswa untuk belajar (Mendiknas, 2008:6).

Selanjutnya, bertolak dari latar belakang di atas maka peneliti mengambil sebuah judul penelitian. Adapaun judul penelitian ini, yaitu "Kajian Arkeptipal dan Nilai Kearifan Lokal dalam Legenda di Kota Purworejo serta Relevansinya sebagai Bahan Ajar Mata Kuliah Apresiasi Prosa.

\section{METODE PENELITIAN}

Pendekatan penelitian yang peneliti gunakan adalah kualitatif. Objek dalam penelitian ini dibedakan menjadi 2 (dua) macam, yaitu objek formal dan material. Menurut Siti Chamamah objek penelitian sastra dibedakan menjadi 2 macam, yaitu objek material dan objek formal. Objek material adalah bahan konkret yang dijadikan sasaran penyelidikan, sedangkan objek formal adalah sudut pandang yang dilakukan oleh peneliti dalam menelaah objek materialnya atau sesuatu yang dibincangkan dalam objek material (Sangidu, 2004:70). Objek material dalam penelitian ini adalah legenda di Kota Purworejo, sedangkan objek formalnya adalah kajian arkeptipal, nilai budaya lokal, dan relevansi pembelajaranya. Teknik pengumpulan data dalam penelitian ini adalah teknik wawancara, dokumentasi, dan catat. Teknik analisis yang peneliti gunakan adalah analisis isi (content analysis). Penarikan kesimpulan adalah satu kegiatan dari konfigurasi yang utuh. Dan membuat rumusan proposisi yang terkait dan mengangkatnya sebagai temuan penelitian (Sugiyono, 2014:89). Penarikan simpulan dalam penelitian ini berupa hasil akhir dari analisis data. Pada tahap penyajian hasil analisis, sistematika yang digunakan adalah meng- 
gunakan model penyajian informal yang merujuk pada metode penyajian hasil analisis.

\section{HASIL PENELITIAN DAN PEMBAHASAN}

Ada dua masalah pokok yang dibahas dalam bagian ini, yaitu (1) kajian arketipal dalam legenda di Purworejo, (2) nilai kearifan lokal dalam legenda di Purworejo, dan (3) relevansinya sebagai bahan ajar pada mata kuliah kajian prosa. Selanjutnya, legenda Purworejo yang akan dibahas ada tiga, yaitu legenda Dewi, Candi Ngasinan, dan Banyuurip. Berikut pemaparan dari tiga persoalan terkait legenda Purworejo tersebut.

\section{Kajian Arkeptipal Legenda di Purworejo}

Dalam legenda Desa Dewi dari dua versi ditemukan beberapa tokoh. Dalam versi A ditemukan tokoh empat tokoh, yaitu Dewi, Sutononggo, Hanggawongso, Ketononggo. Sementara itu, dalam versi B ditemukan empat tokoh, yaitu Dewi, Honggowoso, Ketononggo, dan Setomenggolo. Hal tersebut nampak pada kartu data dengan kode KALD/ 01/ Jumat, 19 Agustus 2016 dan KALD/ 02/ Jumat, 19 Agustus 2016.

Berdasarkan cuplikan kartu data terdapat beberapa tokoh arkeptipal berdasarkan dua versi yang berbeda. Versi pertama, menurut Narasumber Mbah Ponidi, terdapat empat tokoh, yaitu Dewi sebagai tokoh sentral pendiri Desa Dewi, dan tiga pengawalnya, yaitu Sutononggo, Hanggawangsa, dan Ketononggo. Sementara dalam versi kedua, menurut Narasumber Pak Sumarno, terdapat empat tokoh, yaitu Dewi sebagai tokoh sentral pendiri Desa Dewi, Setomenggolo sebagai suami Dewi, dan dua pengawalnya, yaitu Honggowoso dan Ketononggo.

\section{Nilai Kearifan Lokal Desa Dewi}

Nilai-nilai kearifan lokal dalam legenda Desa Dewi meliputi tiga aspek, yaitu: sistem pemerintahan legenda Desa Dewi, sistem mata pencaharian legenda De-sa Dewi, dan sistem perlengkapan hidup warga legenda Desa Dewi. Sistem peme-rintahan dalam legenda Desa Dewi nampak pada kode KFLD/ 01/ Jumat, 19 Agustus 2016. Sistem mata pencaharian dalam legenda Desa Dewi nampak pada kode KFLD/ 02/ Jumat, 19 Agustus 2016. Sistem peralatan dalam legenda Desa Dewi nampak pada kode KFLD/ 03/ Jumat, 19 Agustus 2016.

\section{Kearifan Lokal Legenda Candingasinan}

Kearifan lokal sebagai cerminan budaya masyarakat setempat juga nampak pada cerita legenda Candingasinan. Dalam legenda ini nampak beberapa nilai budaya setempat yang masih ada dan perlu dilestarikan baik berupa sistem pencaharian, peralatan dan perlengkapan, maupun budaya.

Dalam sistem mata pencaharian, legenda Candingasinan memperkenalkan budaya bertani yang dilahirkan oleh tokoh-tokoh legenda seperti Ki Demang Kertopati dan Manggolo Wiropati. Mereka merupakan prajurit yang melarikan diri hingga ke desa Candingasinan dan kemudia menyamar menjadi petani

\section{Nilai Kearifan Lokal dalam Legenda Banyuurip.}

Nilai kearifan lokal terdapat beberapa bentu jenisnya, ada berwujud benda dan ada pula berwujud bahasa. Benda merupakan sesuatu yang bisa dilihat, sedangkan bahasa sesuatu yang tidak dapat dilihat, tetapi bisa digunakan.

Dalam legenda Banyurip terdapat dua Nilai Kearifan lokal. Pertama Benda, wujudnya adalah sumur beji. Sumur 
beji merupakan tempat yang digunakan untuk minum dan aktivitas lainya.

\section{Relevansinya sebagai Bahan Ajar}

Perpres No. 08 tahun 2012 dan UU PT No. 12 Tahun 2012 Pasal 29 ayat (1), (2), dan (3) telah berdampak pada kurikulum dan pengelolaannya di setiap program. Kurikulum yang pada awalnya mengacu pada pencapaian kompetensi menjadi mengacu pada capaian pembelajaran (learning out-comes). Secara ringkas KKNI terdiri dari Sembilan level kualifikasi akademik SDM Indonesia. Dengan adanya KKNI ini diharapkan akan mengubah cara melihat kompetensi seseorang, tidak lagi semata Ijazah tapi dengan melihat kepada kerangka kualifikasi yang disepakati secara nasional sebagai dasar pengakuan terhadap hasil pendidikan seseorang secara luas (formal, nonformal, atau informal) yang akuntanbel dan transparan.

Maka dari hal tersebut, pembelajaran setiap mata pelajaran lebih mengarah kepada mahasiswa walaupun dosen ikut berkontribusi. Pembelajaran sastra di perguruan tinggi diprogramkan oleh pihak kurikulum ataupun progdi untuk membina daya potensi kreativitas mahasiswa, baik dalam ketenengan mental, sikap yang baik, maupun kreativitas berpikir mahasiswa. Apabila pembelajaran berjalan dengan baik, maka program yang dicanangkan akan teraplikasikan di dalam keseharian mahasiswa dan membuat mereka menjadi manusia yang memiliki daya cipta di kehidupan.

Pembelajaran sastra di Perguruan Tinggi tentunya berbeda dengan pembelajaran sastra di di SD, SMP, dan SMA karena pembelajaran sastra di Perguruan Tinggi lebih kreatif dan Produktif. Oleh karena itu, mahasiswa di Perguruan Tinggi tidak dibekali dengan berbagai ilmu pengetahuan tentang ilmu-ilmu sastra, tetapi juga membekali dan melatih mahasiswa untuk meng- hasilkan sebuah karya sastra bagi dirinya sendiri juga masyarakat. Pembelajaran sastra di Perguruan Tinggi sangat ditentukan oleh pendekatan yang digunakan oleh para dosen ketika mengajar sehingga mahasiswa tidak merasa bosan ataupun jenuh ketika belajar sastra. Pembelajaran sastra di perguruan tinggi tentunya melibatkan semua aspek seperti sejarah sastra, keritik sastra, teori sastra, apresaiasi sastra, pengkajian sastra, dll. Oleh karena itu, pembelajaran sastra di Perguruan Tinggi dapat dikatakan berhasil jika dosen berhasil menggunakan pendekatan yang tepat sehingga tidak bosan para mahasiswa dan menikmati pembelajaran sastra tersebut.

Tingkat Perguruan Tinggi pembelajaran sastra sangat beragam, sebab mahasiswa diharuskan untuk memahami beragam jenis karya sastra. Sastra berkaitan erat dengan semua aspek manusia dan alam dengan keseluruhannya. Setiap karya sastra selalu menghadirkan 'sesuatu' dan kerap menyajikan banyak hal yang apabila dihayati benar-benar akan semakin menambah pengetahuan orang yang menghayatinya. Dalam hal pengajaran sastra novel merupakan jembatan untuk melatih kecakapan yang perlu dikembangkan adalah kecakapan yang bersifat indera, penalaran, afektif, sosial dan religius, dengan ini siswa akan lebih menghayati apa yang disampaikan melalui karya sastra.

Pembelajaran sastra juga sangat ditentukan oleh metode atau pendekatan yang ditentukan oleh dosen ketika mengajar. Dengan demikian, pembelajaran sastra yang beraneka ragam tentu penting diajarkan kepada mahasiswa. Selain itu, dosen berperan penting dalam menentukan pendekatan pembelajaran yang tepat guna mengajarkan materi sastra tersebut.

Pembelajaran sastra di Perguruan Tinggi dibentuk untuk membentuk sikap positif terhadap sastra dengan mempu- 
nyai apresiasi tinggi terhadap beragam karya sastra. Selain itu, pembelajaran sastra di Perguruan Tinggi diaharapkan dapat menumbuhkan budaya literasi setiap mahasiswa yang dimaksudkan untuk membiasakan berpikir yang diikuti dengan proses membaca.

Berdasarkan temuan peneliti diketahui bahwa terdapat relevansi legenda di Purworejo dengan pembelajaran di Perguruan Tinggi. Relevansi tersebut terkait dengan: kajian arkeptipal dan nilai kerifan lokal dalam legenda di Purworejo. Lagenda Purworejo yang dianalisis meliputi legenda Dewi, Legenda Brengkelan, legenda Banyuurip, dan legenda Candingasinan bercerita tentang asal mula sebuah desa dan sebagai tokoh pendirinya adalah orang yang baru saja datang. Legenda-legenda ini menandung beberapa nilai kehidupan yang bisa bermanfaat bagi mahasiswa dan pembaca awam.

Kesesuaian pendekatan arkeptipal dan nilai kearifan lokal dengan pembelajaran sastra di Perguruan Tinggi ditunjukan pada silabus mata kuliah pengkajian prosa fiksi. Dalam silabus terdapat materi, pengkajian sastra dengan pendekatan antropologi sastra dan psikologi sastra. Pertama, antropologi sastra dengan pendekatan arkeptipal dan nilai kearifan lokal sangat berkesinambungan, sebab kedua pendekatan ini merupakan bagian pendekatan antropologi sastra yang menitikberatkan pada pendekatan budaya. Kajian arkeptipal yang membahas peristiwa arkeptipal dan simbol arkeptipal berhubungan dengan unsur budaya sehingga sangat relevan dengan pembelajaran sastra materi antropologi sastra. Kajian nilai-nilai kearifan lokal yang membahas tentang sistem pencaharian, simbol, maupun bahasa yang merupakan budaya lokal suatu daerah relevan sekali dengan materi pembelajaran sastra dengan pendekatan antropologi sastra.
Kedua, kajian arkeptipal berkesinambungan dengan pendekatan pendekatan psikologi sastra. Hal tersebut dikarenakan dalam penelaahan arkeptipal yang membahas tentang tokoh arkeptipal relevan dengan materi pembelajaran sastra yang membahas materi pendekatan psikologi sastra yang samasama membahas sifat dasar seorang manusia/tokoh dalam karya sastra.

Selanjutnya, relevansi kajian tersebut dengan materi pembelajaran di perguruan tinggi dapat diuraikan sebagai berikut. Pembelajaran sastra di perguruan tinggi baik, di Program Studi Pendidikan Bahasa dan Satra Indonesia, maupun Sastra Indonesia mencakup beberapa matakuliah penting terkait dengan materi sastra prosa, yaitu sejarah sastra, kritik sastra, teori sastra, apresiasi sastra, kajian sastra, dll. Salah satu mata kuliah sastra yang menitik beratkan pada kegiatan mahasiswa untuk mengkaji prosa adalah mata kuliah kajian prosa. Dalam mata kuliah kajian prosa, mahasiswa diharapkan memahami beragam jenis pendekatan sastra dan mengimplementasinya dalam kegiatan pengkajian prosa. Jenis-jenis pendekatan itu, antara lain: pendekatan struktural, pendekatan psikologi, pendekatan sosiologi, pendekatan feminisme, pendekatan antropologi, pendekatan semiotik, dll.

Dua pendekatan yang berkaitan dengan kajian yang dilakukan peneliti adalah dengan menggunakan pendekatan psikologi dan antropologi. Pendekatan psikologi sastra adalah pendekatan sastra yang digunakan untuk mengkaji kejiwaan maupun kepribadian tokoh. Dalam pendekatan psikologi sastra banyak teori sastra yang digunakan untuk mengkaji karya sastra, seperti Sigmund Freud, Carl Gustav Jung, Alferd Adler, Gestalt, dll. Dalam kaitanya pendekatan psikologi sastra dengan penelitian yang dilakukan peneliti adalah kaitanya dengan tokoh arkeptipal. 
Dalam membahas tokoh arkeptipal, tentu saja membahas beberapa tokoh yang ada dalam tokoh cerita, kepribadian tokoh tersebut, dan penokohanya secara fisik. Sebagai seorang dosen tentu saja harus memberikan contoh melalui sebuah kajian prosa fiksi baik lisan maupun tertulis. Penelitian ini, telah terdapat pengkajian tokoh arkeptipal dalam legenda di Purworejo. Seorang dosen dapat menjelaskan kepribadian tokoh dalam penelitian ini serta kepribadian tokohnya. Misal dalam legenda Babad Banyu Urip, ada tokoh yang bernama Bhra Tanjung, ia adalah raja yang tegas dan berani. Contoh tersebut merupakan ilustrasi kepribadian tokoh yang ada dalam legenda sebagai cara memberikan ilustrasi aspek kepribadian tokoh pada mahasiswa. Mahasiswa dapat memahami contoh kajian perwatakan tokoh serta memahami gam-baran mengkaji dengan pendekatan psikologi sastra aspek kepribadian tokoh. Dengan demikian, penelitian yang dilakukan peneliti ini berkesinambungan dengan pendekatan psikologi sastra dari segi kepribadian tokoh. Oleh karena itu, penelitian yang telah peneliti lakukan dapat digunakan sebagai bahan ajar dalam materi psikologi sastra di Perguruan Tinggi.

Pendekatan yang kedua adalah pendekatan antropologi sastra. Antropologi sastra adalah analisis terhadap karya sastra yang terdapat unsur-unsur antropologi (kebudayaan). Salah satu teori antropologi yang sering digunakan dalam pendekatan karya sastra adalah teorinya Koentjananingrat yang membahas tujuh unsur budaya. Dalam kaitannya pendekatan antropologi sastra dengan penelitian yang dilakukan peneliti adalah kaitanya dengan peristiwa arkeptipal, simbol arkeptipal, dan kearifan lokal. Dalam membahas peristiwa arkeptipal peneliti membahas peristiwa budaya atau peristiwa yang dialami pada tokoh yang ada di dalam karya sastra, simbol arkeptipal membahas tentang simbol-simbol budaya, dan kearifan lokal mencakup unsur budaya lokal yang ada dalam karya sastra baik bahasa, sistem mata pencaharian, maupun simbol. Sebagai seorang dosen tentu saja harus memberikan contoh melalui sebuah kajian prosa fiksi baik lisan maupun tertulis. Penelitian ini, telah terdapat pengkajian peristiwa arkeptipal, simbol arkeptipal, dan kearifan lokal dalam legenda di Purworejo. Seorang dosen dapat menjelaskan unsur-unsur budaya dalam penelitian ini. Misal dalam legenda Babad Banyu Urip, ada simbol arkeptipal berupa sumur dan senjata berupa Ki Panu Biru. Contoh tersebut merupakan ilustrasi simbol budaya yang ada dalam legenda sebagai cara memberikan ilustrasi aspek unsur budaya pada mahasiswa. Mahasiswa dapat memahami contoh simbol buaya serta memahami gambaran mengkaji dengan pendekatan antropologi sastra. Dengan demikian, penelitian yang dilakukan peneliti ini berkesinambungan dengan pendekatan antropologi sastra. Oleh karena itu, penelitian yang telah peneliti lakukan dapat digunakan sebagai bahan ajar dalam materi antropologi sastra di Perguruan Tinggi.

Bahan ajar yang digunakan dalam mata kuliah psikologi sastra maupaun antropologi sastra berwujud dua bentuk, pertama bahan ajar yang berupa pengkajian yang dilakukan peneliti. Kedua, bahan ajar berupa sinopsis legenda yang telah peneliti lakukan. Bahan ajar berupa kajian legenda sebagai contoh kajian prosa baik menggunakan pendekatan psikologi maupaun pendekatan antropologi. Bahan ajar berupa kumpulan sinopsis digunakan sebagai bahan untuk dikaji, baik pendekatan psikologi sastra, antropologi sastra maupaun pendekatan lainya. Bahkan, bahan ajar ini bisa pula digunakan untuk mata kuliah lainya, 
baik kritik sastra, sastra perbandingan, dan mata kuliah folklore.

\section{SIMPULAN}

Adapun simpulan dari penelitian ini antara lain: kajian arkeptipal dalam legenda di Purworejo membahas kajian arkeptipal, kearifan lokal, dan nilai relevansi pembelajaranya. Kajian tersebut terdapat tiga bahasan, yaitu tokoh arkeptipal, peristiwa arkeptipal, dan simbol arkeptipal. Tokoh arkeptipal dalam legenda rata-rata adalah seorang petualang yang menemukan hutan kemudian membabat alas menjadi desa. Tokoh tersebut menjadi nama desa tersebut. Peristiwa arkeptipal berkaitan dengan peristiwa babat alas dan peperangan. Simbol arkeptipal berupa bahasa, peninggalan, dan senjata; kearifan lokal yang ada dalam legenda berupa upacara adat, bahasa, dan mata pencaharian; dan penelitian ini relevan sebagai bahan ajar dalam mata kuliah pengkajian sastra baik materi psikologi sastra maupun antropologi sastra. Bahan ajar tersebut bisa berwujud contoh pengkajian maupun bahan pengkajian.

\section{DAFTAR PUSTAKA}

Ayat, Rohaedi. (1986). Jakarta: Kepribadian budaya bangsa (Local Genius). Pustaka Jaya.

Bacom, Wiliam R. (1984). Four function of folklor. the study of folklore (Alan Dundes ed). Engelwood Clifis: N. J. Pretice Hall.

Griffith, Jr, Kelley. (1982). A writing essays about literature. New York: Harcourt Brace Jovanovich, Inc

Nurgiyantoro, Burhan. (2010). Teori pengskajian fiksi. Yogyakarta: Gadjah Mada Universitay.

Prastowo, Andi. (2012). Panduan kreatif membaca bahan ajar inovatif. Yogyakarta: Diva Press.
Sangidu. (2004). Metode penelitian sastra, pendekatan teori, meto-de dan kiat. Yogyakarta: UGM.

Setyorini, Nurul. (2014). Aspek-aspek Stilistika Novel Lalita Karya Ayu Utami. Jurnal Bahtera, 1 (2), 2133.

Setyorini, Nurul. (2015). Aspek-aspek diksi Novel Mataraisa karya Abidah El Khaileqy dan Novel Larung karya Ayu Utami (Kajian Komparatif). Seminar Nasional dan Lounching Adobsi, Surakarta, 6 Februari 2015.

Wiyatmi. (2010). Konstruksi gender dalam Novel Geni Jora karya Abidah El Khaileqy. Humaniora, 22 (2),196-206. 